\title{
FAS Gene
}

National Cancer Institute

\section{Source}

National Cancer Institute. FAS Gene. NCI Thesaurus. Code C21555.

This gene is involved in the mediation of cellular surface receptors and apoptotic signals. 